Gut, 1971, 12, 197-199

\title{
Gastric acid secretion in sickle-cell anaemia
}

\author{
LADE WOSORNU AND F. I. D. KONOTEY-AHULU \\ From the Departments of Surgery and Medicine and Therapeutics, University of Ghana Medical School, \\ Accra, Ghana
}

SUMMARY The gastric acid response to the augmented histamine test was measured in 115 Ghanaian patients, including 45 cases of sickle-cell anaemia. Normal gastric acid responses were found in the patients with sickle-cell anaemia, suggesting that the frequent occurrence of indigestion in patients with this disorder is unlikely to be related to abnormal gastric acid secretion.

Patients with sickle-cell anaemia often complain of attacks of indigestion and, indeed, the second reported case of the disorder had such symptoms (Washburn, 1910-1911). Most patients attending the Sickle-Cell Clinic in the Korle Bu Teaching Hospital, Accra, also complain of frequent attacks of epigastric pain related to meals, and therefore the possibility that these symptoms might be related to abnormalities of gastric acid secretion seemed worthy of investigation.

Reports on gastric acid secretion in sickle-cell anaemia are conflicting. Early authors thought that hypochlorhydria occurred in this disorder (Sydenstricker, 1924; Alden, 1927), but Zarafonetis, Joseph, McMaster, and Kalas (1961) found normal gastric acid secretion, and Serjeant, Richards, Barbar, and Milner (1968) showed high acid production in two of their patients.

In the present study, acid secretion under both basal and maximally stimulated conditions was measured in Ghanaian patients and a comparison was made between those with and those without the sickle-cell abnormality.

\section{Patients and Methods}

Three groups of patients were studied. In the test group of special interest were 25 men with proven sickle-cell anaemia chosen at random from patients at the Sickle-Cell Clinic, Korle Bu Teaching Hospital, Accra. Forty sickling-negative male patients with radiologically proven duodenal ulcer and 30 other sickling-negative men who had no history of ulcer

Received for publication 3 November 1970.

${ }^{1}$ Requests for reprints may be addressed to Lade Wosornu, the Department of Surgery, Royal Postgraduate Medical School, Hammersmith Hospital, Du Cane Road, London W12. dyspepsia served as controls. Twenty women with sickle-cell anaemia were also studied but the results are excluded because of the lack of female controls with duodenal ulcer, which is exceptionally rare in Ghanaian women.

The augumented histamine test (Kay, 1953) was performed after an overnight fast in all patients. After collecting basal secretion in periods of 15 minutes for one hour, $50 \mathrm{mg}$ of mepyramine maleate was injected intramuscularly, followed half an hour later by subcutaneous injection of histamine acid phosphate in a dose of $0.04 \mathrm{mg} / \mathrm{kg}$ body weight. Collection of the secretory response after histamine was continued for one further hour, measurements being made every 15 minutes. The volume and $p \mathrm{H}$ of all specimens of gastric juice were measured. Acid output was determined by titration against $\mathrm{N} / 10$ sodium hydroxide to $p \mathbf{H} 7.0$ with phenol red as an indicator. For both basal and post-histamine secretion, the volumes and acid outputs were calculated as hourly rates simply by the addition of the appropriate four successive values.

\section{Results}

Table $I$ is a summary of the age and weight of the men studied and Table II gives the mean hourly values for volume and acid in spontaneous and stimulated secretion ('basal hour' and 'augmented histamine hour') respectively in this group. The individual data on acid output are shown in the Figure.

Student's $t$ test was applied to test the statistical significance of differences in the values for volume and acid in the basal hour and augmented histamine hour between the three groups. There was no significant difference between the mean values for patients 


\begin{tabular}{lll}
\hline & Mean Age and Range $(y r)$ & Mean Weight and Range $(\mathrm{kg})$ \\
\hline Stickling-positive patients (25) & $21 \cdot 4(12-40)$ & $49 \cdot 0(25 \cdot 5-65 \cdot 5)$ \\
Sickling-negative patients (70) & $34 \cdot 8(18-55)$ & $57 \cdot 5(40 \cdot 4-74 \cdot 5)$ \\
Normal $^{1}(30)$ & $35 \cdot 4(12-60)$ & $56 \cdot 2(24 \cdot 1-72 \cdot 8)$ \\
\hline
\end{tabular}

Table I Age and weight of male patients studied

${ }^{1}$ Without history of ulcer dyspepsia.

\begin{tabular}{|c|c|c|c|c|c|c|c|c|}
\hline & \multicolumn{8}{|c|}{ Acid Output } \\
\hline & \multicolumn{4}{|c|}{ Basal Hour } & \multicolumn{4}{|c|}{ Augmented Histamine Hour } \\
\hline & \multicolumn{2}{|c|}{ Volume $(\mathrm{ml})$} & \multicolumn{2}{|c|}{ Acid (m-equiv) } & \multicolumn{2}{|c|}{ Volume $(\mathrm{ml})$} & \multicolumn{2}{|c|}{ Acid (m-equiv) } \\
\hline & Mean & $S D$ & Mean & $S D$ & Mean & $S D$ & Mean & $S D$ \\
\hline $\begin{array}{l}\text { Sickling-postitive patients (25) } \\
\text { Sickling-negative patients (70) }\end{array}$ & $92 \cdot 3$ & $46 \cdot 6$ & $3 \cdot 2$ & 3.4 & $159 \cdot 2$ & $58 \cdot 5$ & $11 \cdot 4$ & $7 \cdot 6$ \\
\hline $\begin{array}{l}\text { Normal }^{1}(30) \\
\text { Duodenal ulcer }(40)\end{array}$ & $\begin{array}{l}101 \cdot 0 \\
120 \cdot 9\end{array}$ & $\begin{array}{l}56 \cdot 5 \\
60 \cdot 0\end{array}$ & $\begin{array}{l}2 \cdot 8 \\
6 \cdot 0\end{array}$ & $\begin{array}{l}3 \cdot 8 \\
6 \cdot 4\end{array}$ & $\begin{array}{l}167 \cdot 6 \\
247 \cdot 8\end{array}$ & $\begin{array}{l}69 \cdot 5 \\
90 \cdot 0\end{array}$ & $\begin{array}{r}9 \cdot 8 \\
24 \cdot 4\end{array}$ & $\begin{array}{r}6 \cdot 1 \\
14 \cdot 0\end{array}$ \\
\hline
\end{tabular}

Table II Mean hourly values for volume and acid in the basal and augmented histamine hours

${ }^{1}$ Without history of dyspepsia.

with sickle-cell anaemia and 'normal' patients who had neither sickle-cell anaemia nor ulcer dyspepsia. However, the mean values for sickling-negative patients with duodenal ulcer were significantly greater than the mean values for both the sickle-cell anaemia patients $(P<0.01)$ and the normal patients $(\mathrm{P}<0.001)$.

Desai, Borker, and Jeejeebhoy (1967) found a significant relationship between total body weight and the augmented histamine response in subjects weighing between 40 and $60 \mathrm{~kg}$. In this study we found an insignificant correlation between these two variables (Table III). Therefore, it seems unlikely that these differences in body weight would explain the differences in secretory responses observed.

\begin{tabular}{lllc}
\hline Series & $\begin{array}{l}\text { No. of } \\
\text { Patients }\end{array}$ & $\begin{array}{l}\text { Regression of } y \text { (acid augmented } \\
\text { histamine hour) on } x \text { (weight) }\end{array}$ & $r$ \\
\hline $\begin{array}{l}\text { Sickling-positive } \\
\text { Sickling-negative }\end{array}$ & 25 & $y=0.24 x-0.50$ & 0.3 \\
Normals & 30 & $y=0.08 x+14.24$ & -0.1 \\
Duodenal ulcer & 40 & $y=0.05 x+27.29$ & -0.03 \\
\hline
\end{tabular}

Table III Relation between weight and augmented histamine response

${ }^{2}$ Without history of ulcer dyspepsia.

\section{Discussion}

Washburn (1910-1911) stated of the second reported case of sickle-cell anaemia that 'after eating the patient occasionally had severe abdominal pains and is often troubled with indigestion'. Serjeant et al
(1968) obtained a history of epigastric pain after meals, which awoke the patients at night and was frequently relieved by milk, food, or alkali, in 20 patients (33\%) of their series. The clinical impression from patients at the Sickle-Cell Clinic in the Korle $\mathrm{Bu}$ Teaching Hospital, Accra, is consistent with these observations.

The cause of these gastric symptoms is not known and it appears reasonable to ask whether gastric acid secretion in sickle-cell anaemia differs from that in the sickling-negative population. Hypochlorhydria was blamed by earlier workers. For example, Syndenstricker (1924) stated that: 'The gastric symptoms which we have associated with splenic haemorrhages and infarcts ... may be due to achylia in some cases'. Jones, Wetzel, and Black (1948) commented on the 'commonly observed hypochlorhydria' in patients with sickle-cell traits, a statement which appears to have been based on a single gastric analysis reported by Alden in 1927. There may be a little uncertainty regarding these earlier reports in view of the techniques used to measure gastric secretion; the concept of an 'augmented' or 'maximal' acid response had not been evolved at that time.

In his comprehensive review on sickle-cell anaemia Margolies (1951) pointed out that 'the evidence that achylia or hypochlorhydria is a cause for gastric symptoms is not good'. Zarafonetis et al (1961) performed the 'histalog test' using 50 mghistalog subcutaneously in 10 cases of sickle-cell anaemia and 10 controls and concluded that "contrary to earlier literature, patients with sickle-cell haemoglobin usually 


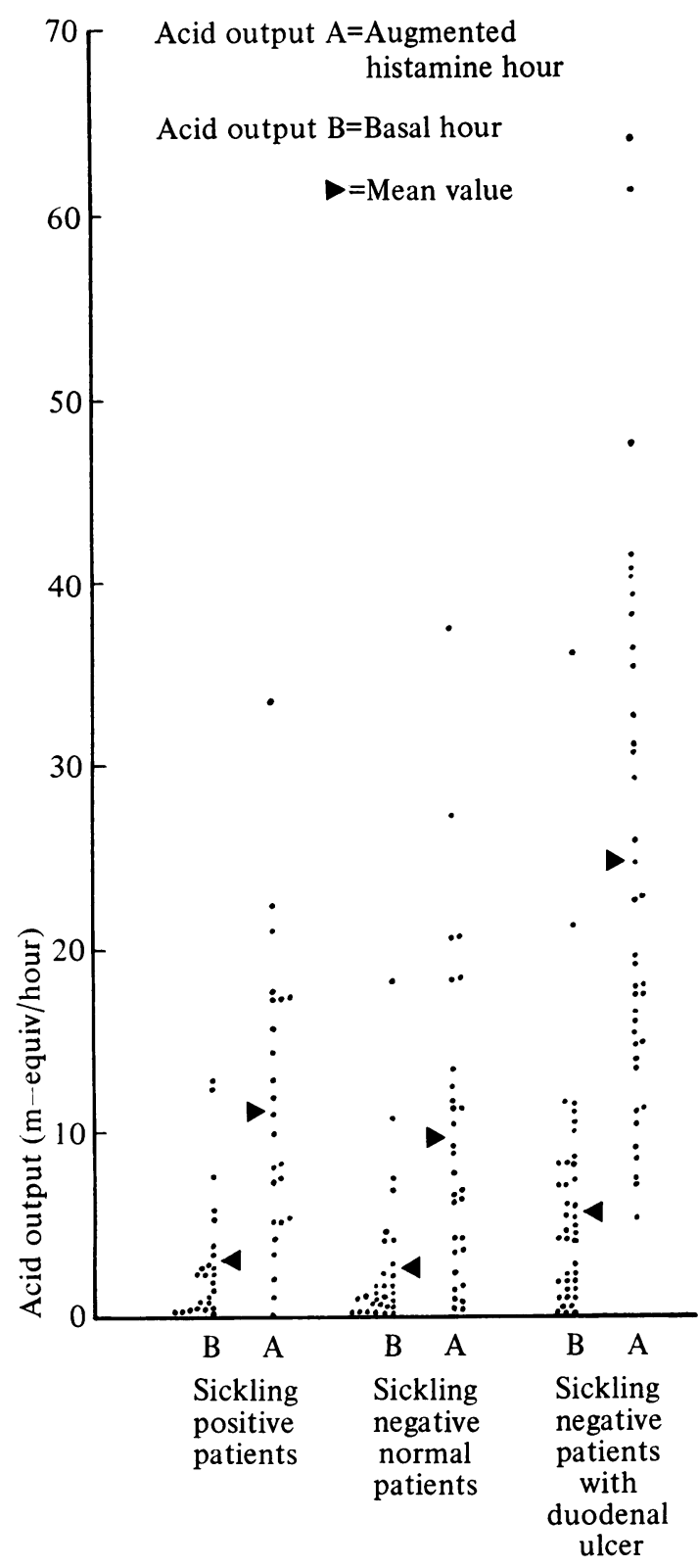

Fig. Scattergram of individual results of acid output. The mean values in each group are arrowed.

have normal gastric secretory responses'. Serjeant et al (1968), using the augmented histamine test, reported high acid production in two of their patients, but this is hardly surprising since both patients had proven duodenal ulceration.

We found no statistically significant difference between the mean hourly values for acid secretion in response to an augmented dose of histamine in patients with sickle-cell anaemia and in sicklingnegative patients without indigestion. However, sickling-negative patients with duodenal ulcer secreted significantly more acid than the patients with sickle-cell anaemia.

Duodenal ulcer is said to be rare in sickle-cell anaemia (Hein, McCalla, and Thorne, 1927; Jones et al, 1948; Margolies, 1951). The present studies appear to indicate that the occurrence of the sicklecell trait does not exclude the development of duodenal ulcer, since some patients with sickle-cell anaemia did secrete acid in amounts similar to those observed in some of the patients with duodenal ulcer (Fig.). It remains to be established whether the incidence of this latter disorder is similar to or different from that of the normal population.

We are grateful to Mr J. N. A. Nunno for the mathematical calculations and to Mr Alan G. Cox for valuable suggestions.

\section{References}

Alden, H. S. (1927). Sickle-cell anemia; report of two cases from Ohio illustrating its hemolytic nature. Amer. J. med. Sci., 173, 168-175.

Desai, H. G., Borkar, A. V., and Jeejeebhoy, K. N. (1967). Doseweight relationship of histamine for maximal stimulation of gastric acid secretion. Gastroenterology, 53, 712-718.

Hein, G. E., McCalla, R. L., and Thorne, G. W. (1927). Sickle-cell anemia with report of a case with autopsy. Amer. J. med. Sci., 173, 763-772.

Jones, H. L., Jr., Wetzel, F. E., and Black, B. K. (1948). Sickle-cell anemia with striking electrocardiographic abnormalities and other unusual features, with autopsy. Ann. intern. Med., 29, 928-935.

Kay, A. W. (1953). Effect of large doses of histamine on gastric secretion of HC1: an augmented histamine test. Brit. med. J., 2, 77-80.

Margolies, M. P. (1951). Sickle-cell anemia: A composite study and survey. Medicine (Baltimore), 30, 357-443.

Serjeant, G. R., Richards, R., Barbor, P. R. H., and Miller, P. R. (1968). Relatively benign sickle-cell anemia in 60 patients aged over 30 in the West Indies. Brit. med. J., 3, 86-91.

Sydenstricker, V. P. (1924). Sickle-cell anemia. Sth. med. J. (Bgham, Ala.), 17, 177-183.

Washburn, R. E. (1910-1911). Peculiar elongated and sickle-shaped red blood corpuscles in a case of severe anemia. Virginia Med. (Semimth). 15, 490-493.

Zarafonetis, C. J. D., Joseph, R., McMaster, J. D., and Kalas, J. P. (1961). Osmolarity of gastric secretions in sicklemic individuals. J. Lab. clin. Med., 57, 600-603. 